\title{
South American Rattlesnake (Crotalus durissus spp.) Envenomation in Dogs in the Semiarid Region of Brazil
}

\author{
Mizael Machado' , Clarice Ricardo de Macêdo Pessoa², André Flávio Almeida Pessoa², Rodrigo de Souza Mendes ${ }^{3}$, \\ Rosane Maria Trindade de Medeiros ${ }^{4}$, Antônio Flávio Medeiros Dantas ${ }^{4}$, \\ Márcio Botelho de Castro ${ }^{5}$ \& Franklin Riet-Correa ${ }^{1}$
}

\begin{abstract}
Background: South American rattlesnake (Crotalus durissus spp.) envenomation is rarely reported in small animals and livestock in Brazil. Minor swelling at the snakebite site, skeletal muscle, and renal damage, and severe neurological signs characterize the crotalic envenomation. This case report aims to present epidemiological, clinical, and pathological data of two cases of Crotalus durissus spp envenomation in dogs in the Northeast of Brazil.

Cases: Envenomation by Crotalus durissus spp. was recorded in two dogs in Patos, State of Paraíba, Brazil. In Case 1, the dog presented flaccid paralysis, hyporeflexia, a deficit of cranial nerves, epistaxis, and gingival hemorrhages. Laboratory assay showed proteinuria, myoglobinuria, regenerative thrombocytopenia, and increased serum activities of creatine kinase (CK), aspartate aminotransferase (AST), alanine aminotransferase (ALT), and alkaline phosphatase (ALP). The dog was medicated with crotalic antivenom and wholly recovered from local and systemic clinical signs. In Case 2, the dog died and was detected fang marks at the ventral region of the left mandible (two small parallel perforations spaced $2.0 \mathrm{~cm}$ apart) at the snakebite site. Cyanosis of the oral cavity, congestion, and hemorrhages in several organs were observed at necropsy. Tubular nephrosis, muscular necrosis, hepatocytes swelling were observed. The owners witnessed snakebites, and the rattlesnakes (Crotalus durissus spp.) identified by the rattle at the end portion of the tail in both cases.

Discussion: Natural South American rattlesnake envenomation presents complex clinical signs that makes diagnosis a challenge for veterinary practitioners. The criteria for the correct diagnosis and observed in the two dogs include witness of the snakebite, identification of the snake, detection of fang marks, clinical-pathological findings, and therapeutic response to treatment with specific anti-venom. The dog's owners did not identify the subspecies of rattlesnakes; however, Crotalus durissus cascavella and Crotalus durissus collilineatus are the only species found in the Northeast region of Brazil. Crotoxin is the primary toxic component of South American rattlesnake, which induces neuromuscular blockage, and neurological signs (skeletal muscle flaccid paralysis, apathy, hyporeflexia, cranial nerve deficits). These clinical signs are similar to those observed in the two dogs. Respiratory distress, cyanosis, pulmonary edema, and hemorrhage are secondary to respiratory muscle paralysis and also detected in a dog (Case 2) with crotalic envenomation. Minor local swelling at the snakebite site, myotoxicity observed in both dogs (high serum activities of CK and AST - Case 1), degeneration and necrosis of muscle fibers - Case 2), and fang marks observed in Case 2, strengthen the diagnosis of Crotalus durissus envenomation. Nephrotoxicity was also detected in both dogs (increased specific gravity of urine - Case 1 and myoglobin deposition and degeneration of renal epithelial tubular cells - Case 2). Coagulative disorders and hepatotoxicity are infrequently in domestic animals and humans with crotalic envenomation. High serum activities of ALP and ALT in Case 1, and swelling of hepatocytes in Case 2, suggest liver damage associated with the crotalic envenomation. The differential diagnosis of South American rattlesnake envenomation should be included in dogs with acute neuromuscular flaccid paralysis, associated or not with bleeding disorders, myoglobinuria, and acute kidney injury.
\end{abstract}

Keywords: Crotalus durissus spp., dog, snakebite, crotalic envenomation, toxic myopathy.

${ }^{1}$ Instituto Nacional de Investigación Agropecuaria (INIA), Tacuarembó, Uruguay. ${ }^{2}$ Universidade Federal de Sergipe (UFS), Campus do Sertão, Nossa Senhora da Glória, SE, Brazil. ${ }^{3}$ Escola de Saúde, Universidade Potiguar (UnP), Natal, RN, Brazil. ${ }^{4}$ Centro de Saúde e Tecnologia Rural (CSTR), Universidade Federal de Campina Grande (UFCG), Patos, PB, Brazil. ${ }^{5}$ Laboratório de Patologia Veterinária, H.V., Universidade de Brasília (UnB), Brasília, DF, Brazil. CORRESPONDENCE: F. Riet-Correa [frcorrea@inia.org.uy]. Instituto Nacional de Investigación Agropecuaria - INIA. Ruta 5, Km 386. Z.C. 45.000 Tacuarembó, Uruguay. 


\section{INTRODUCTION}

South American rattlesnake (Crotalus durissus spp.) envenomation induces severe clinical signs in domestic animals and humans, mainly characterized by neuromuscular impairment, rhabdomyolysis and acute kidney injury (AKI). Effects of the Crotalus venom include reduced local reaction at the snakebite site, neurological signs, respiratory failure, nephrotoxicity, and coagulation disorders [24].

Snakebites cause death and substantial economic loss in domestic animals worldwide; however, reports of epidemiological, pathological, and clinical data are still scarce [6]. Crotalic envenomation presents a small frequency in humans (8 to 20\%) in comparison with reports of bothropic envenomation (80 to 90\%) in Brazil [10]. Natural bothropic envenomation is also more frequent in dogs and cats [20,22,35], and in farm animals [19,23,38].

Natural Crotalus durissus terrificus envenomations have been rarely reported in dogs in Brazil [8] and Argentina [18], and there are no cases reported in livestock [36]. Experimental crotalic envenomations have been conducted in dogs [33], cattle [11], and horses [21] to evaluate clinical and pathological changes. Considering the rarity in domestic animals, this report aims to provide information on clinical signs, laboratory, gross and histopathological findings of two natural cases of crotalic envenomation in dogs in the Northeast of Brazil.

\section{CASES}

\section{Case 1}

An adult male mongrel dog was admitted for veterinary care $38 \mathrm{~h}$ after a rattlesnake snakebite witnessed by the owner in the municipality of Patos, Paraíba State (PB), Northeastern Brazil. Clinical signs included apathy, hyporeflexia, flaccid paralysis of limbs, paralysis of the ocular muscles, anisocoria, fascial and trigeminal nerve deficits (Figure $1 \mathrm{~A}$ ), reduced lingual muscle tonus, dehydration, congestion of oral and ocular mucosae, epistaxis and bleeding through the mouth. The swelling of the dorsolateral nasal region was detected at the snakebite site. Serial complete blood cell count (Table 1) revealed thrombocytopenia, macroplatelets, neutrophilia, and monocytosis. Proteinuria, severe myoglobinuria, and high urine specific gravity (1.060) were also detected. Creatine kinase (CK), aspartate aminotransferase (AST), alanine aminotransferase (ALT), and alkaline phospha- tase (ALP) serum activities were increased even when the patient was discharged (Table 2).

One day before, the dog was in recumbency, lethargic, anorexic, and blind. Three ampoules of 20 $\mathrm{mL}$ of polyvalent antivenom (Master Soro Plus $\left.{ }^{\circledR}\right)^{1}$ capable of neutralizing up to $90 \mathrm{mg}$ of crotalic venom were administered intramuscularly. Significant clinical improvement occurred $5 \mathrm{~h}$ after administration of the antivenom, and the animal was fully recovered 6 days after the incident.

Case 2

The owner witnessed the snake biting of an adult male mongrel dog in the municipality of Patos, PB, Brazil. The animal presented mainly nervous signs similar to case 1 and later was comatose. The dog died after a clinical evolution of nearly $24 \mathrm{~h}$ and was taken for necropsy. The main gross findings were fang marks (two small parallel perforations spaced $2.0 \mathrm{~cm}$ apart) surrounded by hemorrhages in the skin and subcutaneous tissues on the ventral side of the left jaw (Figure $1 \mathrm{~B}$ ). The oral mucosa and tongue were cyanotic, and the lungs presented multifocal petechiae and suffusions. The kidneys were diffusely red-brown with moderate cortical pallor.

Histologically, moderate edema and congestion in the dermis and muscles, marked rhabdomyolysis (hyaline and floccular necrosis) characterized by hyalinization of muscle fibers, loss of striations and fragmentation (Figure $2 \mathrm{~A}$ ) were observed at the snakebite site. Multifocal inflammatory infiltrate of neutrophils, some lymphocytes, plasma cells, and rare macrophages were also detected surrounding the fang marks. Kidneys presented acute severe tubular necrosis, cellular debris, hyaline, and granular casts in the lumen of the tubules (Figure 2 B). The affected tubules had a brownish pigment (myoglobin) in the cytoplasm of the remaining epithelial cells. Other gross findings included multifocal areas of hemorrhage and edema in the lungs, and liver with congestion of centrilobular and diffuse hydropic degeneration of hepatocytes.

The owners of dogs in Cases 1 and 2 killed and identified the rattlesnakes by the terminal portion of the tail. Unfortunately, the identification of the subspecies of South American rattlesnake was not conducted.

\section{DISCUSSION}

Crotalus spp. envenomations in domestic animals have been infrequently reported in Brazil. In dogs, as well as in other domestic animals and humans, 


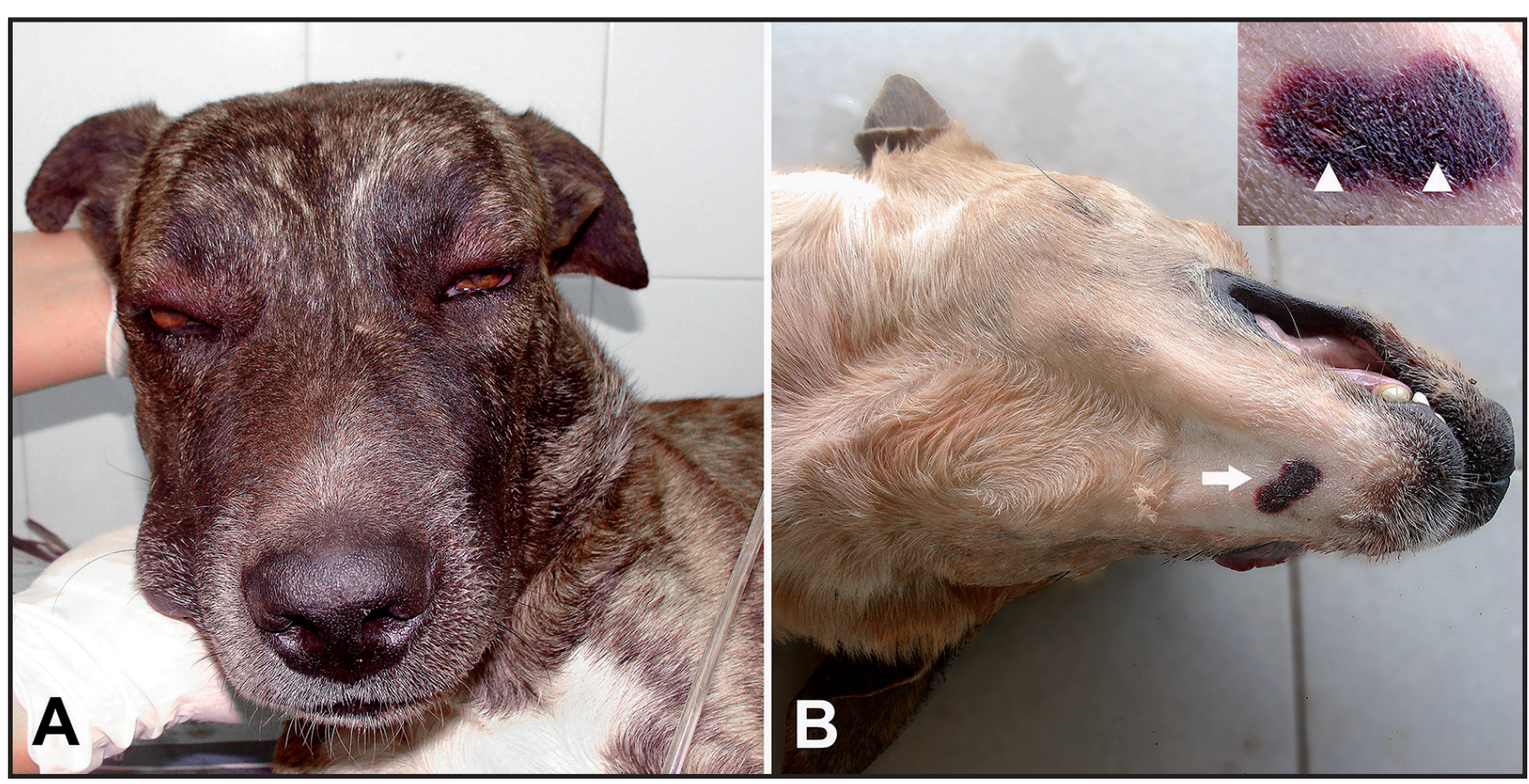

Figure 1. Crotalus envenomation in dogs. A(Case 1)- Bilateral palpebral ptosis and mild swelling at the face. B(Case 2)- Skin. Suffusion at the rattlesnake bite site on the ventral left side of the jaw (arrow). Close view: two fang marks (arrow heads) interspaced $2.0 \mathrm{~cm}$ apart.

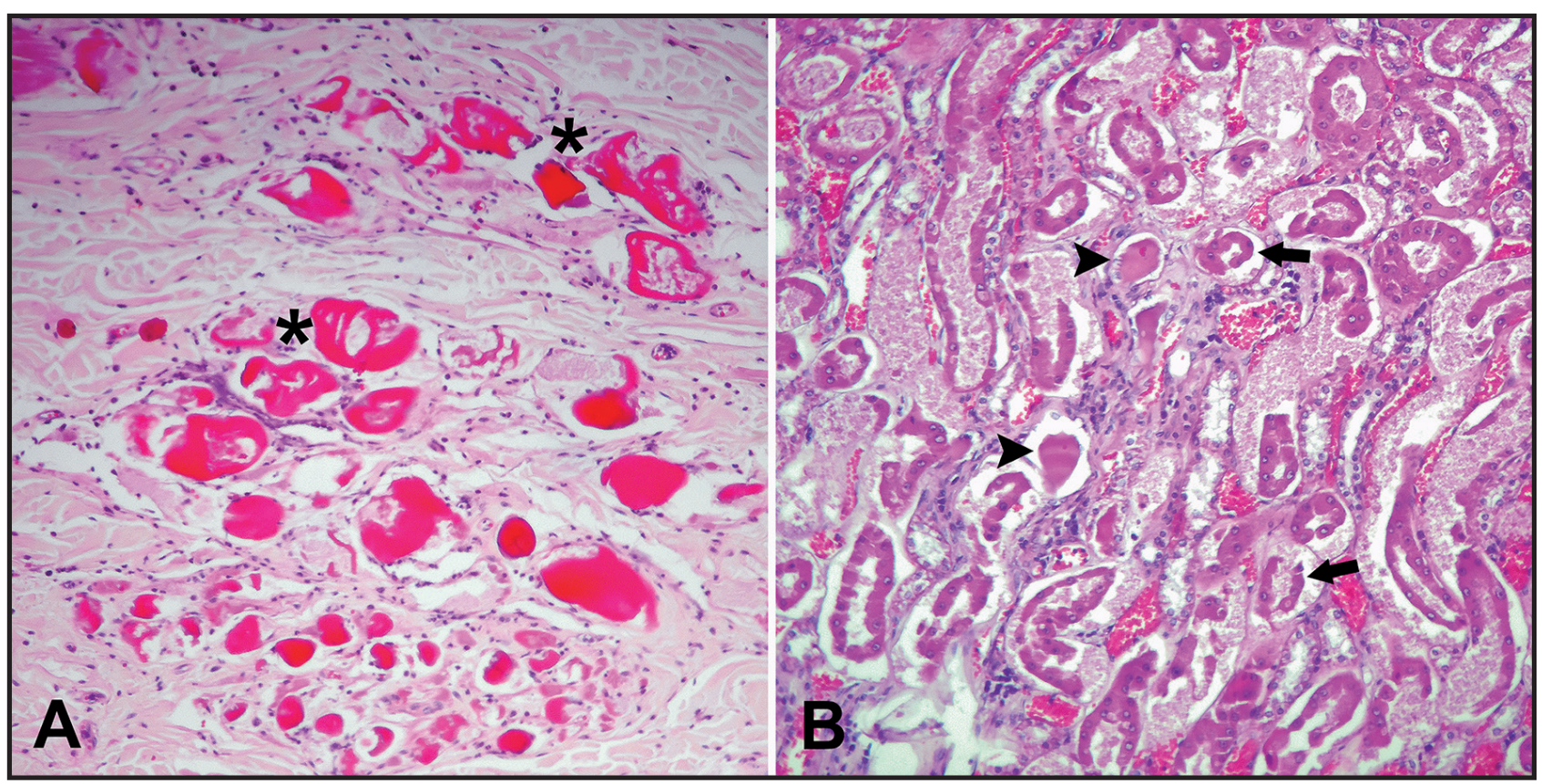

Figure 2. Crotalus envenomation in a dog (Case 2). A- Snakebite site, skin. Hyalinization and necrosis of muscle fibers (asterisk) [H\&E, 400x]. BKidney. Tubular necrosis (arrows) and hyaline casts in the lumen of the tubules (arrow heads) [H\&E, 200x].

crotalic envenomation presents complex clinical and pathological changes that make it a challenge for the correct diagnosis. The main criteria for the determination of crotalic envenomation, and observed in two dogs in the Northeastern of Brazil include: witness of the snakebite, identification of the snake, detection of fang marks, clinical-pathological findings and also a therapeutic response to the treatment with specific anti-venom.
Crotalic envenomation presents a complex diagnosis, and snake identification is one of the most important criteria. In both cases, the owners identified South American rattlesnakes by the presence of a rattle on the terminal portion of the tail. Snakebites in domestic animals are rarely witnessed, which makes it challenging to identify the genus of snakes to institute appropriate treatment [5]. Crotalus durissus is the unique species of the genus Crotalus in Brazil with 
Table 1. Complete blood cell count in a dog (Case 1) with natural Crotalus envenomation.

\begin{tabular}{|c|c|c|c|c|}
\hline \multirow[t]{2}{*}{ Parameter } & \multicolumn{3}{|c|}{ Number of days after envenomation } & \multirow[t]{2}{*}{ Reference range* } \\
\hline & 2 & 3 & 6 & \\
\hline Erythrocytes $\left(\mathrm{x} 10^{6} / \mu \mathrm{L}\right)$ & $6.5^{\mathrm{a}}$ & 4.5 & 6.5 & $5.5-8.5$ \\
\hline Hematocrit (\%) & 43 & 30 & 38 & $37-55$ \\
\hline Hemoglobin (g/dL) & 14.5 & 10.2 & 14.4 & $12-18$ \\
\hline White blood cells $(\mu \mathrm{L})$ & 24,450 & $\mathrm{ND}^{\#}$ & 22,700 & $6,000-17,000$ \\
\hline \multicolumn{5}{|l|}{ Neutrophils } \\
\hline Segmented $(\mu \mathrm{L})$ & 18,620 & ND & 16,117 & $3,000-11,500$ \\
\hline Bands $(\mu \mathrm{L})$ & 980 & ND & 227 & $0-300$ \\
\hline Lymphocytes $(\mu \mathrm{L})$ & 1,960 & ND & 2,724 & $1,000-4,800$ \\
\hline Eosinophils ( $\mu \mathrm{L})$ & 0 & ND & 1,135 & $100-1,250$ \\
\hline Monocytes $(\mu \mathrm{L})$ & 2,940 & ND & 2,497 & $150-1,350$ \\
\hline Platelets $(\mu \mathrm{L})$ & $96,000^{\mathrm{b}}$ & 72,000 & 246,000 & $200,000-500,000$ \\
\hline
\end{tabular}

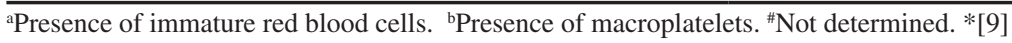

Table 2. Serum biochemistry of a dog (Case 1) with natural Crotalus envenomation.

\begin{tabular}{ccccccc}
\hline Parameter & \multicolumn{5}{c}{ Number of days after envenomation } & Reference range $^{*}$ \\
\cline { 2 - 6 } CK (U/L) & 2 & 3 & 4 & 5 & 6 & \\
AST (U/L) & - & 5,173 & 995 & 728 & 655 & $<125$ \\
ALT (U/L) & 591 & 204 & 94 & 57 & 52 & $10-88$ \\
ALP (U/L) & 151 & 125 & 78 & 73 & 73 & $21-102$ \\
Urea nitrogen (mg/dL) & 331 & 398 & 265 & 232 & 207 & $20-156$ \\
Creatinin (mg/dL) & 0.7 & 0.8 & 0.5 & 0.7 & 1.0 & $21-60$ \\
Protein (g/dL) & 7.7 & 4.4 & 5.5 & 5.3 & 5.8 & $5.5-1.5$ \\
Albumin (g/dL) & 2.3 & 2.3 & 2.6 & 2.4 & 2.9 & $2.6-3.3$ \\
\hline
\end{tabular}

$\mathrm{CK}=$ creatine kinase; $\mathrm{AST}=$ aspartate aminotransferase; $\mathrm{ALT}=$ alanine aminotransferase; $\mathrm{ALP}=$ alkaline phosphatase; ${ }^{*}[17]$.

two subspecies, Crotalus durissus cascavella and $C$. d. collilineatus present both in Northeastern Brazil [2].

Clinical findings observed in Cases 1 and 2 were mainly constituted by nervous signs such as skeletal muscle flaccid paralysis, apathy, hyporeflexia, cranial nerve deficits, and comatose state were similar to that observed in dogs naturally envenomed by Crotalus spp. $[8,18]$, and in cattle and horses experimentally envenomed with crotalic venom $[11,21]$. Crotoxin, a potent neurotoxin, is the main component in the venom of the South American rattlesnakes [7], which blocks presynaptic transmission at the neuromuscular junctions [2].
Cyanosis observed in Case 2 possibly reflects a respiratory insufficiency associated with muscle impairment, similarly to that reported in cases of Crotalus spp. envenomation in humans [15]. Pulmonary edema and hemorrhage detected in experimental envenomation with $C$.durissus venom [27], may also cause respiratory distress contributing to cyanosis.

Dogs with crotalic envenomation showed mild local reactions such as minor swelling, erythema, and fang marks at the snakebite site. Local changes at the snakebite site in South American rattlesnake envenomation may be absent or with mild tissue reactions (edema and erythema), and making it difficult to iden- 
tify [24]. In contrast, the North American rattlesnake envenomation, frequently induces tissue necrosis at the snakebite site due to the action of proteolytic enzymes and myotoxins contained within the venom $[1,13]$. Although both snakes belong to the Crotalus genus, variations in venom composition between South and North American rattlesnakes [24] may explain differences in local reaction at the snakebite site.

Muscle necrosis observed in Case 2 was similar to those found in cattle experimentally inoculated with C.durissus venom [11]. The myotoxic action induces injury on muscle fibers types I and II [31] mainly due to the major crotalic venom toxin (crotoxin) properties [28]. Additionally, crotamine, another component of C. durissus venom, induces depolarization of the sarcolemma, calcium influx into the myofiber, and cell death [32]. The increase in serum CK and AST activities in Case 1 and the pathological muscular changes in Case 2 reflected the myotoxic effect and muscle necrosis of crotalic venom in dogs. Local reaction and muscle necrosis at the snakebite site possibly triggered the neutrophilia with mild left shift detected in Case 1.

Renal lesions detected in Case 2 are characteristic of acute tubular necrosis, secondary to myoglobin deposition in renal tubules and myoglobinuria. Despite normal serum levels of urea and creatinine, the dog (Case 1) presented proteinuria associated with elevated urine specific gravity suggesting acute tubular injury. Crotoxin is also considered the main fraction of $C$. durissus venom that induces acute kidney injury [12,25,26], which is regarded as one of the most important causes of death (29\%) in human patients envenomed by $C$. durissus [29].

Nephrotoxicity was not recognized in experimental crotalic envenomation in livestock in Brazil [37]. In our two cases of $C$. durissus envenomation in dogs, myoglobinuria and nephrotoxicity were significant findings similar to that reported in humans [24]. Acute tubular necrosis and myoglobin deposition in renal tubular cells detected in a dog in Northwestern Brazil (Case 2), highlights the relevance of the nephrotoxicity in the crotalic envenomation and probably contributed to the animal's death.

Hemorrhages in organs, tissues, and at the snakebite site occurred in both envenomed dogs, and also thrombocytopenia in Case 1. Severe cases of $C$. durissus envenomation in humans are also character- ized by hemorrhages [34], coagulative disorders, and these changes were not reported in envenomed dogs in the Southeast of Brazil and Argentina $[8,18]$.

Increased clotting time and afibrinogenemia are common findings in most human cases of crotalic envenomation in Brazil [14,16]. Gyrotoxin, a component of crotalic venom, presents a thrombin-like action triggering blood clotting through several pathways, inducing thrombosis, defibrinogenation, and in some cases, disseminated intravascular coagulation. Convulxin, a platelet aggregator, has been suggested to play an additional role in the pathogenesis of hemorrhage in Crotalus durissus envenomation [30]. Hemorrhages and thrombocytopenia observed in two dogs with crotalic envenomation, strengthen the importance of hemostatic disorders induced by the South American rattlesnake venom.

Crotalic venom can also induce degeneration, necrosis, and mitochondrial injury of hepatocytes associated with an increase of pro-inflammatory cytokines and high ALP and ALT serum activities [3,4]. Dogs with crotalic envenomation reported here present ALP and ALT serum activities increased in Case 1, and hepatic degeneration and injury in Case 2.

The differential diagnosis of Crotalus durissus spp. snakebites include Micrurus sp. or Lachesis sp. envenomations in patients with neurologic signs [24]. Other diseases characterized by a flaccid paralysis such as botulism, organophosphates and carbamates poisoning, tick paralysis, polyradiculoneuritis (Coonhound paralysis), and myasthenia gravis should also be considered in differential diagnoses of Crotalus envenomation in dogs. South American rattlesnake envenomation diagnostic criteria are poorly reported in domestic animals in Brazil. Our report aims to improve the crotalic envenomation diagnosis allowing fast and correct therapeutics and reducing the lethality.

\section{MANUFACTURER}

${ }^{1}$ Laboratórios Vencofarma do Brasil Ltda. São Paulo, SP, Brazil.

Acknowledgments. Thanks are due to Dr. José María Gutiérrez (University of Costa Rica) for the critical reading of the manuscript and suggestions.

Declaration of interest. The authors report no conflicts of interest. The authors alone are responsible for the content and writing of the paper. 


\section{REFERENCES}

1 Aragão A.P., Tokarnia C.H., Graça F.A.Z., França T.N., Coelho C.D., Caldas A.S. \& Peixoto P.V. 2010. Envenenamento experimental por Bothropoides jararaca e Bothrops jararacussu em ovinos: aspectos clínicopatológicos e laboratoriais. Pesquisa Veterinária Brasileira. 30(9): 717-728.

2 Barraviera B. 1999. Acidentes por serpentes dos gêneros Crotalus e Micrurus. In: Barraviera B. (Ed). Venenos: as pectos clínicos e terapêuticos dos acidentes por animais peçonhentos. Rio de Janeiro: EPUB., pp.281-290.

3 Barraviera B., Bonjorno-Júnior J.C., Arakaki D., Domingues M.A., Pereira P.C., Mendes R.P., Machado J.M. \& Meira D.A. 1989. A retrospective study of 40 victims of Crotalus snake bites. Analysis of the hepatic necrosis observed in one patient. Revista da Sociedade Brasileira de Medicina Tropical. 22(1): 5-12.

4 Barraviera B., Coelho K.Y., Curi P.R. \& Meira D.A. 1996. Liver dysfunction in patients bitten by Crotalus durissus terrificus (Laurenti, 1768) snakes in Botucatu (state of São Paulo, Brazil). Revista do Instituto de Medicina Tropical São Paulo. 37(1): 59-69.

5 Bicudo P.L. 1999. Acidentes ofídicos em Medicina Veterinária. In: Barraviera B. (Ed). Venenos: aspectos clínicos e terapêuticos dos acidentes por animais peçonhentos. Rio de Janeiro: EPUB., pp. 375-387.

6 Bolon I., Finat M., Herrera M., Nickerson A., Grace D., Schütte S., Martins S.S. \& Castañeda R.R. 2019. Snakebite in domestic animals: First global scoping review. Preventive Veterinary Medicine. 170: doi.org/10.1016/j.prevetmed.2019.104729

7 Calvete J.J., Sanz L., Cid P., Torre P., Flores-Diáz M., Santos M.C., Borges A., Bremo A., Ângulo Y., Lomonte B., Alape-Girón A. \& Gutiérrez J.M. 2010. Snake venomics of the Central American rattlesnake Crotalus simus and the South American Crotalus durissus complex points to neurotoxicity as an adaptive paedomorphic trend along crotalus dispersal in South America. Journal of Proteome Research. 9(1): 528-544.

8 Collichio R.C., Sakate M., Balarin M.R.S., Hataka A.K., Roseli P., Viana L. \& Nogueira F.S. 2002. Relato de caso: Alterações clínicas e laboratoriais consequentes à picada de cascavel (Crotalus durissus terrificus) em uma cadela gestante. Clínica Veterinária. 40: 45-48.

9 Feldman B.F., Zinkl J.G. \& Jain N.C. 2000. Normal hematology of the dog. In: Meinhoth J.H. \& Clinkenbearb (Eds). Schalm's Veterinary Hematology. 5th edn. Philadelphia: Lippincott Williams \& Wilkins., pp.1057-1063.

10 Ferreira Júnior R.S. \& Barraviera B. 2004. Management of venomous snakebites in dogs and cats in Brazil. Journal of Venomous Animals and Toxins including Tropical Diseases. 10(2): 112-132.

11 Graça F.A.S., Peixoto P.V., Coelho C.D., Caldas S.A. \& Tokarnia C.H. 2008. Aspectos clínicos e patológicos do envenenamento crotálico experimental em bovinos. Pesquisa Veterinária Brasileira. 28(6): 261-270.

12 Hadler W.A. \& Vital Brazil O. 1966. Pharmacology of crotoxin IV nephrotoxicity. Memórias do Instituto Butantan. 33: 1001-1008.

13 Holstege C.P., Miller M.B., Wermuth M., Furbee B. \& Curry S.C. 1997. Crotalid snake envenomation. Critical Care Clinics. 13(4): 889-921.

14 Jorge M.T. \& Ribeiro L.A. 1988. Incoagulabilidade sangüínea no acidente crotálico. Revista do Instituto de Medicina Tropical de São Paulo. 21: 121-133.

15 Jorge M.T. \& Ribeiro L.A. 1992. Epidemiologia e quadro clínico do acidente por cascavel sul-americana (Crotalus durissus). Revista do Instituto de Medicina Tropical de São Paulo. 34(4): 347-354.

16 Kamiguti A.S. \& Cardoso J.LC.1989. Haemostatic changes caused by the venoms of South American snakes. Toxicon. 27(9): 955-963.

17 Kaneko J.J., Harvey J.W. \& Bruss M.L. 1997. Appendix IX. Blood analyte reference values in small and some laboratory animals. In: Clinical Biochemistry of Domestic Animals. San Diego: Academic Press, pp.895-899.

18 Koscinczuk P., Pérez O.A., Teibler P., Maruñak S. \& Rosciani A.S. 2000. American rattlesnake (Crotalus durissus terrificus) bite accidents in dogs in Argentina. Arquivo Brasileiro de Medicina Veterinária e Zootecnia. 52(2): 125-129.

19 Leal M.L.R., Aires A.M.C., Fillapi A. \& Trost M.E. 2013. Clinical and pathological observations associated with snake envenemotion in two sheep. Acta Scientiae Veterinariae. 41: 32.

20 Lima R.L., Braga P.V., Pelegrini N.F., Almeida A.B.P.F., Mendonça A.J., Strüssmann C. \& Sousa V.R.F. 2019. Acidente botrópico em cães. Acta Scientiae Veterinariae. 47: 401. doi: 10.22456/1679-9216.93268. 
21 Lopes C.T.A., Tokarnia C.H., Brito M.F., Sousa M.G.S., Oliveira C.M.C., Silva N.S., Lima D.H.S. \& Barbosa J.D. 2012. Aspectos clínico-patológicos e laboratoriais do envenenamento crotálico experimental em equinos. Pesquisa Veterinária Brasileira. 32(9): 843-849.

22 Machado M., Wilson TM., Sousa DER., Martins CS. \& Castro M.B. 2018. Pit viper envenomation in a barn cat. Journal of Small Animal Practice. 60(2): 131. doi.org/10.1111/jsap.12922

23 Machado M., Wilson TM., Sousa DER., Câmara ACL., Furlan FH., Macêdo JTSA., Pupin RC., Lemos RAA., Armién AG., Barros SS., Riet-Correa F. \& Castro M.B. 2019. Fatal lancehead pit viper (Bothrops spp.) envenomation in horses. Toxicon. 170: 41-50.

24 Malaque C.M.S. \& Gutiérrez J.M. 2015. Snakebite Envenomation in Central and South America. Critical Care Toxicology. 1-22. doi: 10.1007/978-3-319-20790-2_146-1

25 Martins A.M., Toyama M.H., Havt A., Novello J.C., Marangoni S., Fonteles M.C. \& Monteiro H.S. 2002. Determination of Crotalus durissus cascavella venom components that induce renal toxicity in isolated rat kidneys. Toxicon. 40(8): 1165-1171.

26 Monteiro H.S., Silva, I.M., Martins A.M. \& Fonteles M.C. 2001. Actions of Crotalus durissus terrificus venom and crotoxin on the isolated rat kidney. Brazilian Journal of Medical and Biological Research. 34(10): 1347-1352.

27 Nonaka P.N., Amorim C.F., Peres A.C.P., Silva C.A.M., Zamuner S.R., Ribeiro W., Cogo J.C., Vieira R.P., Dolhnikoff M. \& Oliveira L.V.F. 2008. Pulmonary mechanic and lung histology injury induced by Crotalus durissus terrificus snake venom. Toxicon. 51(7): 1158-1166.

28 Oguiura N., Boni-Mitake M. \& Rádis-Baptista G. 2005. New view on crotamine, a small basic polypeptide myotoxin from South American rattlesnake venom. Toxicon. 46(4): 363-370.

29 Pinho F.M.O., Zanetta D.M.T. \& Burdmann E.A. 2005. Acute renal failure after Crotalus durissus snakebite: A prospective survey on 100 patients. Kidney International. 67 (5): 659-667.

30 Prado-Franceschi J., Tavares D.Q., Hertel R. \& Araújo A.L. 1981. Effects of convulxin, a toxin from rattlesnake venom, on platelets and leukocytes of anesthetized rabbits. Toxicon. 9(5): 661-666.

31 Salvini T.F., Amaral A.C., Miayba E.H., Turri J.A., Danella P.M. \& Araújo H.S.S. 2001. Sistemic skeletal muscle necrosis induced by crotoxin. Toxicon 39(8): 1141-1149.

32 Sampaio S.C., Hyslop S., Fontes M.R.M., Prado-Franceschi J., Zambelli V.O., Magro A.J., Brigatte P., Gutierrez V.P. \& Cury Y. 2010. Crotoxin: Novel activities for a classic b-neurotoxin. Toxicon. 55(6): 1045-1060.

33 Sangiorgio F., Sakate M., Nogueira R.M.B. \& Tostes R.A. 2008. Histopathological evaluation in experimental envenomation of dogs with Crotalus durissus terrificus venom. Journal of Venomous Animals and Toxins including Tropical Diseases. 14(1): 82-99.

34 Sano-Martins I.S. \& Santoro M.L. 2003. Distúrbios hemostáticos em envenenamentos por animais peçonhentos no Brasil. In: Cardoso J.L.C., França F.O.S., Wen F.H., Malaque C.M.S.A. \& Haddad Júnior V. (Eds). Animais Peçonhentos no Brasil: biologia, clínica e terapêutica dos acidentes. São Paulo: Sarvier, pp.289-309.

35 Silva L.G., Panziera W., Lessa C.A.S. \& Driemeier D. 2018. Epidemiological and clinical aspects of ophidian bothropic accidents in dogs. Pesquisa Veterinária Brasileira. 38(11): 2146-2149.

36 Tokarnia C.H.\& Peixoto P.V.2006. The importance of snake bites as cause of cattle death in Brazil. Pesquisa Veterinária Brasileira. 26(2): 55-68.

37 Tokarnia C.H., Brito M.F., Barbosa J.D. \& Döbereiner J. 2014. Quadros clínico-patológicos do envenenamento ofídico por Crotalus durissus terrificus e Bothrops spp. em animais de produção. Pesquisa Veterinária Brasileira. 34(4): 301- 312.

38 Tokarnia C.H., Brito M.F., Malafaia P. \& Peixoto P. V. 2008. Snake bite accident in sheep by Bothrops jararaca. Pesquisa Veterinária Brasileira. 28(12): 643-648. 